\title{
ІНФОДЕМІОЛОГІЯ
}

\author{
(c) Kaidashev I., Morokhovets H., Rodinkova V., Bilous O., DuBuske L. M., Bousquet J.
}

УДК 616.211-002(477)

DOI https://doi.org/10.31718/mep.2020.24.5-6.01

\section{PATTERNS IN GOOGLE TRENDS TERMS REPORTING RHINITIS AND ALTERNARIA SEASON IN UKRAINE}

\author{
Kaidashev I. ${ }^{1}$, Morokhovets H. ${ }^{1}$, Rodinkova V. ${ }^{2}$, Bilous O. ${ }^{2}$, DuBuske L. M. ${ }^{3}$, Bousquet J. ${ }^{4,5,6}$ \\ ${ }^{1}$ Ukrainian Medical Stomatological Academy, Department of Internal Medicine No.3 with Phthisiology, Research Department, Poltava, \\ Ukraine \\ ${ }^{2}$ National Pirogov Memorial Medical University, Pharmacy Department, Vinnytsya, Ukraine \\ ${ }^{3}$ Immunology Research Institute of New England, USA \\ ${ }^{4}$ University Hospital, Montpellier, France \\ ${ }^{5}$ MACVIA-France, Fondation partenariale FMC VIA-LR, Montpellier, France \\ ${ }^{6}$ VIMA. INSERM U 1168, VIMA : Ageing and chronic diseases, Epidemiological and public health approaches, Villejuif, Université Ver- \\ sailles St-Quentin-en-Yvelines, UMR-S 1168, Montigny le Bretonneux, France and Euforea, Brussels, Belgium
}

This article presents a literary review on the issue of using the innovative Web-based surveillance tools provided by Google Trends (GT) in order to determine the precise onset of the mold spore season. Mold allergy is a considerable trigger for the development of widespread respiratory disorders - allergic rhinitis and asthma, chronic obstructive pulmonary diseases, etc. The study aimed to examine the seasonality of GT queries in Ukraine with Alternaria pollen counts. Spores of the genus Alternaria belong to one of the most prevailing constituents of the air in all regions of the world. They form infectious inoculum of numerous plant species as well as severe inhaled allergies. A precise definition of the mold spore season onset is crucial to confirm the mold allergy diagnosis and to develop personalized treatment for patients with allergic rhinitis and asthma. The most comprehensive approach is the development of a pan-European sentinel network, which combines all these strategies. GT may be a useful tool in the differentiation of the mold spore seasons, especially when they overlap as in the case of Ambrosia. Four terms "running nose", "tears", "dyspnea", and "cough" (in Cyrillic equivalents) are required in Ukraine to account for Alternaria spore exposure. The combination of GT tools with spore counts may be used in large-scale epidemiological studies. The development of a pan-European sentinel network for allergic diseases has raised the problem of translating the Google search terms into different European languages. GT analysis is a tool to improve and tailor our communication with patients and the general public along with building our sentinel network languages. Our data can be used as a successful tool for allergy patients to prevent or minimize exposure during the mold spore season.

Ключові слова: Alternaria, Google Trends, алергія, алергічний риніт, астма.

У статті представлено літературний огляд проблеми використання інноваційних інструментів веб-спостереження, зокрема Google Trends (GT), з метою визначення точного початку сезону спор цвілі. Алергія на цвіль $\epsilon$ значним пусковим механізмом розвитку поширених респіраторних розладів - алергічного риніту та астми, хронічного обструктивного захворювання легень тощо. Метою дослідження було вивчення сезонності запитів GT в Україні з кількістю спор Alternaria. Спори роду Alternaria - найпоширеніша складова повітря у всіх регіонах світу, що утворюють інфекційний посівний матеріал численних видів рослин, а також спричиняють важку інгаляційну алергію. Точне визначення настання сезону спор цвілі $\epsilon$ вирішальним для підтвердження діагнозу алергії на цвіль та розробки персоналізованого лікування для пацієнтів з алергічним ринітом та астмою. Найбільш комплексним підходом є розвиток загальноєвропейської мережі моніторингу, яка поєднує всі ці стратегії. GT може бути корисним інструментом для диференціації сезонів спор Alternaria, особливо коли вони співпадають з сезоном цвітіння амброзії. Чотири терміни "нежить", "сльози", "задишка" та "кашель" (кирилицею) слід використовувати в Україні для пояснення впливу спор Alternaria. Поєднання запитів GT з кількістю спор може бути використано в масштабних

*To cite this English version: Igor Kaidashev, Halyna Morokhovets, Viktoriia Rodinkova, Olena Bilous, Lawrence M. DuBuske, Jean Bousquet. Patterns in Google Trends Terms Reporting Rhinitis and Alternaria Season in Ukraine. // The Medical and ecological problems. - 2020. - Vol 24, № 5-6. - P. 3-6. 
епідеміологічних дослідженнях. Розвиток загальноєвропейської сигнальної мережі моніторингу алергічних захворювань зумовлює проблему перекладу пошукових термінів різними європейськими мовами. Отримані результати можна використовувати як ефективний інструмент запобігання або мінімізації впливу алергену на пацієнтів під час сезону Alternaria.

Keywords: Alternaria, Google Trends, allergy, allergic rhinitis, asthma.

\section{Introduction}

Alternaria alternata is a risk factor for developing asthma. Alt a 1, which has been described as the major allergen in A. alternata, shows a good correlation with A. alternata spores only when they have germinated [1]. Several studies have found that there is a noticeable correlation between the severity of allergic diseases and the proteolytic activity of Alternaria extracts. The activation of airway epithelial cells with fungus Alternaria enhances lung eosinophilia, peribronchial infiltration, and epithelial mucus production, which are typical symptoms in asthma. It is for this reason that research into the structure and properties of mold allergens should be continued, as new knowledge in this area would make it possible to improve the biochemical quality of the tests and vaccines widely available in the pharmaceutical industry [2].

GT may be a useful tool in the differentiation of the pollen seasons, especially when they overlap as in the case of Artemisia/Ambrosia. Three terms, "allergy," "hay fever," and "ragweed" (in Cyrillic equivalents), are required in Ukraine to account for ragweed pollen exposure. The combination of GT tools with pollen counts may be used in large-scale epidemiological studies. The combination of GT tools with pollen counts may be used in large-scale epidemiological studies [3,5]. GT analysis is a tool to improve and tailor our communication with patients and the general public along with building our sentinel network languages [10].

Patients with monovalent lgE allergies to molds are at a higher risk for asthma than patients with other allergies. Their asthma is often more intense and less controlled as compared to that of patients with other types of allergies [4]. Patients with allergy to molds have a clinically milder type of AR; however, they have a significantly greater predisposition for bronchial asthma. The value of FeNO did not correlate with any type of allergen, but it was significantly higher in patients with monovalent allergy to molds [7]. The study further adds to the existing knowledge on the clinical behavior of the allergic phenotype of COPD by demonstrating fungal sensitization due to other, non-Aspergillus fungi such as $A$. alternata, $S$. commune and Rhizopus spp. Therefore, it would be prudent to monitor fungus sensitized COPD patients for clinical worsening or development of allergic bronchopulmonary mycoses [8]. Severe asthma with fungal sensitization is characterized by the early onset of the disease and high serum levels of interleukin-33. Multiple fungal sensitization is associated with poor asthma control [16].

Spores of the genus Alternaria belong to one of the most prevailing constituents of the air in all regions of the world. They form infectious inoculum of numerous plant species as well as severe inhaled allergies [14].
The most common form of non-invasive fungal sinusitis is the so-called fungus ball. AFRS is more likely to occur in warm, moist climates that favor the growth of fungi [6]. Prolonged exposure to Alternaria thus induces symptoms closer to those associated with dust mite or dander allergy than to those triggered by pollen, although the latter may contribute to the severity of the allergic response [9]. Exposure and sensitivity to ubiquitous airborne fungi such as Alternaria alternata have long been implicated in the development, onset, and exacerbation of chronic allergic airway disorders [11]. The most intense exposure to A. alternata allergens is likely to occur outdoors; however, Alternaria and other allergenic fungi can colonize in indoor environments and thereby increase the fungal aeroallergen exposure levels. A consequence of human exposure to fungal aeroallergens, sensitization to A. alternata, has been unequivocally associated with increased asthma severity [12]. Fungal allergy is clearly linked to a subset of chronic rhinosinusitis (CRS) known as allergic fungal rhinosinusitis (AFRS). This condition represents an intense allergic response against colonizing fungi giving rise to the formation of allergic (eosinophilic) mucin, mucostasis, and sinus opacification [13]. Cladosporium is the most frequently detected airborne mold, whereas Alternaria is the most prevalent with regard to the sensitization rate. Patients' symptoms score significantly correlated to spore concentrations [14]. The fungus pattern often shows a pronounced seasonal periodicity and with fluctuations related to meteorological conditions. In hypersensitive patients, Alternaria spores can induce decreases in respiratory functions and development of allergic symptoms between May and September, being especially more influential in August [15].

Objectives. The study aimed to examine the seasonality of GT queries in Ukraine with Alternaria pollen counts.

Methods. We used GT to search Google queries concerning mold allergy: "allergy", "running nose", "mold", "asthma", "tears" and "cough". The Cyrillic terms in Ukrainian and Russian were used. Pollen collection for 2009-2017 was conducted using volumetric methods. Average daily temperatures were obtained from the website http://gismeteo.ua. Correlations were studied by using Pearson and Spearman tests.

Results. The Alternaria spore season typically started at the end of August and the beginning of September.

The mold spore season started with a concentration of spores of $25 \mathrm{~m}^{-3}$. A maximal peak of Alternaria spores was up to $500 \mathrm{~m}^{-3}$ during the observation period. The termination of the autumn season was at the end of October (Figure 1). 
$R=0.3720$

$P=0.0561$

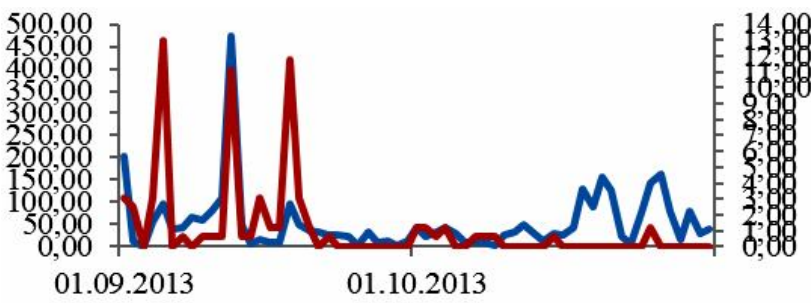

Alternaria count $\longrightarrow$ Ragweed pollen count

A)

$R=0.4975$

$P=0.0002$

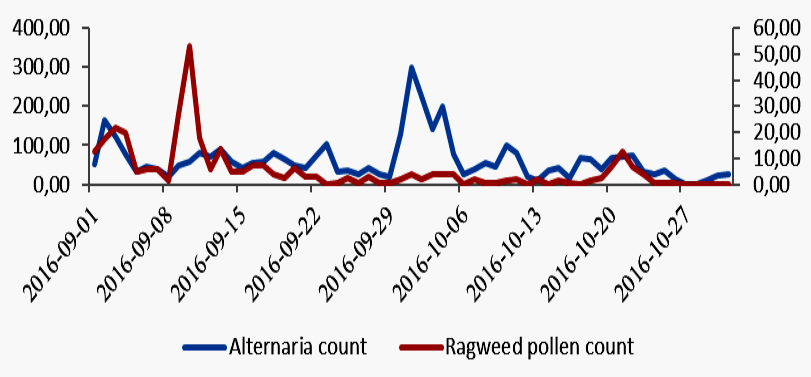

C)
$R=0.7373$

$P<0.001$

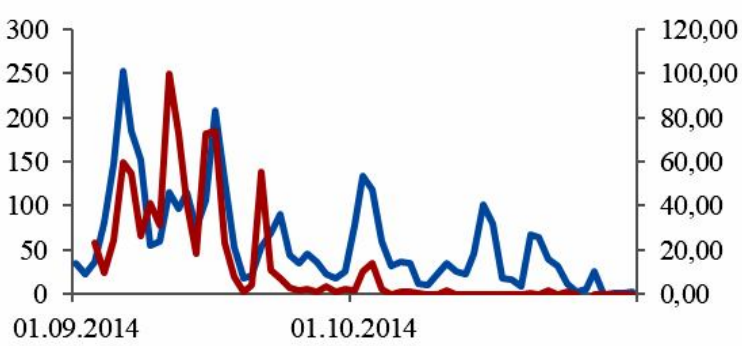

Alternaria count $\longrightarrow$ Ragweed pollen count

B)

$R=0.5780$

$P<0.001$
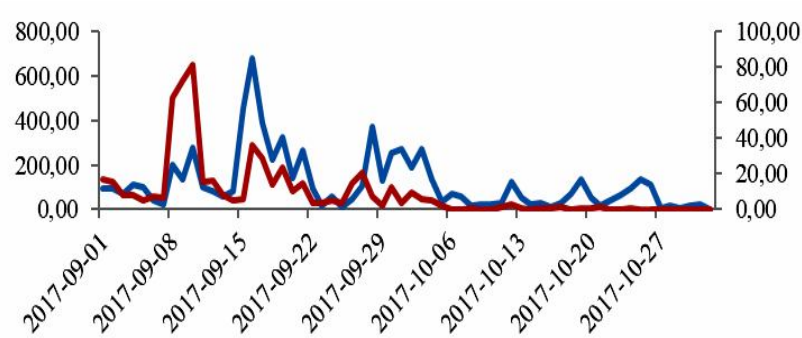

-Alternaria count $\longrightarrow$ Ragweed pollen count

D)

Fig. 1. Four-year Alternaria and ragweed pollination profiles.

$A$ - 2013; $B$ - 2014; C - 2016; $D$ - 2017; $y$-axis - pollen and spore count, grains $m^{-3} ; x$-axis - date.

The terms "running nose", "tears", "dyspnea" and "cough" in Cyrillic are required in Ukraine to calculate the mold spore exposure by GT ( Figure 2).

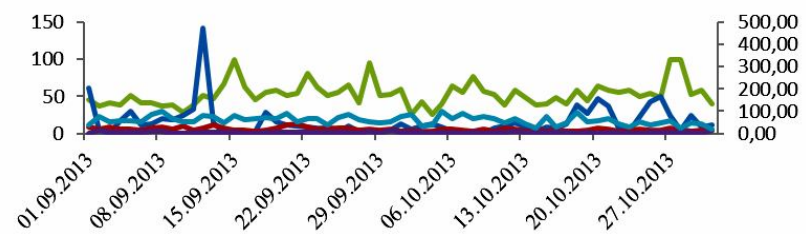

cough $\longrightarrow$ Alternaria spore count $\longrightarrow$ tears $\longrightarrow$ dyspnoe $\longrightarrow$ running nose

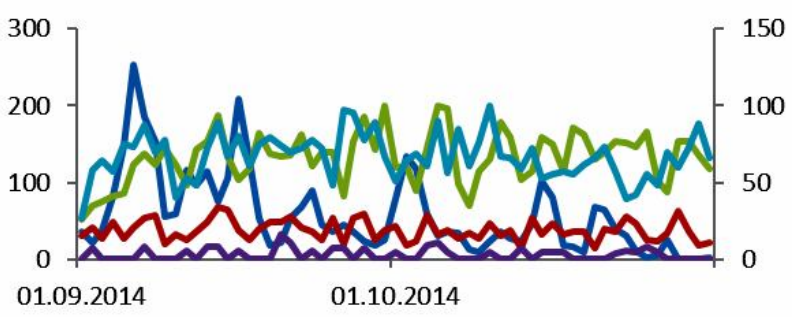

Alternaria spore count
cough

B)

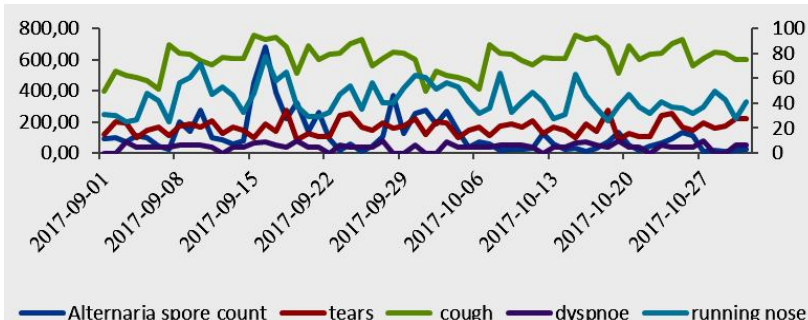

D)

C)

Fig. 2. Four-year Google Trends for "tears", "cough", "dyspnea", "running nose"

using manually translated terms (Cyrillic) and Alternaria spore count.
$A-2013 ; B-2014 ; C-2016 ; D-2017 ; y$-axis - GT queries per day and Alternaria spore count, grains $m^{-3} ; x$-axis - date. 


\section{Conclusions}

GT may be a useful tool in the differentiation of the mold spore seasons, especially when they overlap as in the case of Ambrosia. Four terms "running nose", "tears", "dyspnea", and "cough" (in Cyrillic equivalents) are required in Ukraine to account for Alternaria spore exposure. The combination of GT tools with spore counts may be used in large-scale epidemiological studies.

\section{References}

1. Feo Brito $\mathrm{F}$, Alonso AM, Carnés J, Martín-Martín R, Fernández-Caldas E, Galindo PA, Alfaya T, Amo-Salas M. Correlation between Alt a 1 levels and clinical symptoms in Alternaria alternata-monosensitized patients. J Investig Allergol Clin Immunol. 2012;22(3):154-9. PMID: 22697004.

2. Kustrzeba-Wójcicka I, Siwak E, Terlecki G, WolańczykMędrala A, Mędrala W. Alternaria alternata and its allergens: a comprehensive review. Clin Rev Allergy Immunol. 2014 Dec;47(3):354-65. doi: 10.1007/s12016-014-8447-6. PMID: 25205364.

3. Kaidashev I, Morokhovets H, Rodinkova V, Bousquet J. Patterns in Google Trends Terms Reporting Rhinitis and Ragweed Pollen Season in Ukraine. Int Arch Allergy Immunol. 2019;178(4):363-369. doi: 10.1159/000495306. Epub 2019 Feb 13. PMID: 30759448.

4. Bartra J, Belmonte J, Torres-Rodriguez JM, CisteroBahima A. Sensitization to Alternaria in patients with respiratory allergy. Front Biosci (Landmark Ed). 2009 Jan 1;14:3372-9. doi: 10.2741/3459. PMID: 19273281.

5. Kołodziejczyk K, Bożek A, Jarząb J, Gawlik R. The clinical differences of asthma in patients with molds allergy. Pneumonol Alergol Pol. 2016;84(2):81-6. doi: 10.5603/PiAP.2016.0005. PMID: 27238165.

6. Bousquet J, Agache I, Berger U, Bergmann KC, Besancenot JP, Bousquet PJ, Casale T, d'Amato G, Kaidashev I, Khaitov M, Mösges R, Nekam K, Onorato GL, Plavec D, Sheikh A, Thibaudon M, Vautard R, Zidarn M. Differences in Reporting the Ragweed Pollen Season Using Google Trends across 15 Countries. Int Arch Allergy Immunol. 2018;176(3-4):181-188. doi: 10.1159/000488391. Epub 2018 May 9. PMID: 29742519.

7. Leszczyńska J, Stryjewska-Makuch G, Lisowska G, Kolebacz B, Michalak-Kolarz M. Fungal sinusitis among patients with chronic rhinosinusitis who underwent endoscopic sinus surgery. Otolaryngol Pol. 2018 Jun 20;72(4):35-41. doi: 10.5604/01.3001.0012.1263. PMID: 30190445.

8. Kołodziejczyk K, Bozek A. Clinical Distinctness of Allergic Rhinitis in Patients with Allergy to Molds. Biomed Res Int. 2016;2016:3171594. doi: 10.1155/2016/3171594. Epub 2016 May 31. PMID: 27340656; PMCID: PMC4906200.

9. Kołodziejczyk K, Bozek A. Clinical Distinctness of Allergic Rhinitis in Patients with Allergy to Molds. Biomed Res Int. 2016;2016:3171594. doi: 10.1155/2016/3171594. Epub 2016 May 31. PMID: 27340656; PMCID: PMC4906200.

10. Agarwal K, Gaur SN, Chowdhary A. The role of fungal sensitisation in clinical presentation in patients with chronic obstructive pulmonary disease. Mycoses. 2015 Sep;58(9):531-5. doi: 10.1111/myc.12352. Epub $2015 \mathrm{Jul}$ 22. PMID: 26201384.

11. Aira MJ, Rodríguez-Rajo FJ, Fernández-González $M$, Seijo C, Elvira-Rendueles B, Abreu I, Gutiérrez-Bustillo M, Pérez-Sánchez $E$, Oliveira $M$, Recio $M$, Tormo $R$, Morales J. Spatial and temporal distribution of Alternaria spores in the Iberian Peninsula atmosphere, and meteorological relationships: 1993-2009. Int J Biometeorol. 2013 Mar;57(2):265-74. doi: 10.1007/s00484-012-0550-x. Epub 2012 May 6. PMID: 22562500.

12. Bousquet J, Agache I, Anto JM, Bergmann KC, Bachert C, Annesi-Maesano I, Bousquet PJ, D'Amato G, Demoly P, De Vries G, Eller E, Fokkens WJ, Fonseca J, Haahtela T, Hellings PW, Just J, Keil T, Klimek L, Kuna P, Lodrup Carlsen KC, Mösges R, Murray R, Nekam K, Onorato G, Papadopoulos NG, Samolinski B, Schmid-Grendelmeier P,
Thibaudon $M$, Tomazic $P$, Triggiani $M$, Valiulis $A$, Valovirta E, Van Eerd M, Wickman M, Zuberbier T, Sheikh A. Google Trends terms reporting rhinitis and related topics differ in European countries. Allergy. 2017 Aug;72(8):1261-1266. doi: 10.1111/all.13137. Epub 2017 Mar 13. PMID: 28140507.

13. Babiceanu MC, Howard BA, Rumore AC, Kita H, Lawrence $C B$. Analysis of global gene expression changes in human bronchial epithelial cells exposed to spores of the allergenic fungus, Alternaria alternata. Front Microbiol. 2013 Jul 19;4:196. doi: 10.3389/fmicb.2013.00196. PMID: 23882263; PMCID: PMC3715730.

14. Bousquet J, Schunemann HJ, Fonseca J, ... MACVIAARIA Sentinel NetworK for allergic rhinitis (MASK-rhinitis): the new generation guideline implementation. Allergy. 2015 Nov;70(11):1372-92. doi: 10.1111/all.12686. Epub 2015 Sep 13. PMID: 26148220.

15. Gabriel MF, Postigo I, Tomaz CT, Martínez J. Alternaria alternata allergens: Markers of exposure, phylogeny and risk of fungi-induced respiratory allergy. Environ Int. 2016 Apr-May;89-90:71-80. doi: 10.1016/j.envint.2016.01.003. Epub 2016 Jan 28. PMID: 26826364

16. Hamilos DL. Allergic fungal rhinitis and rhinosinusitis. Proc Am Thorac Soc. 2010 May;7(3):245-52. doi: 10.1513/pats.200909-098AL. PMID: 20463255.

17. Kasprzyk I, Rodinkova V, Šaulienè I, Ritenberga O, GrinnGofron A, Nowak M, Sulborska A, Kaczmarek J, Weryszko-Chmielewska E, Bilous E, Jedryczka M. Air pollution by allergenic spores of the genus Alternaria in the air of central and eastern Europe. Environ Sci Pollut Res Int. 2015 Jun;22(12):9260-74. doi: 10.1007/s11356-014-40706. Epub 2015 Jan 17. PMID: 25592912; PMCID: PMC4473279.

18. Lehmann S, Sprünken A, Wagner N, Tenbrock K, Ott H. Clinical relevance of lgE-mediated sensitization against the mould Alternaria alternata in children with asthma. Ther Adv Respir Dis. 2017 Jan;11(1):30-39. doi: 10.1177/1753465816680786. Epub 2016 Dec 14. PMID: 28043213; PMCID: PMC5941980.

19. Katotomichelakis M, Nikolaidis C, Makris M, Proimos E, Aggelides X, Constantinidis TC, Papadakis CE, Danielides $\mathrm{V}$. Alternaria and Cladosporium calendar of Western Thrace: Relationship with allergic rhinitis symptoms. Laryngoscope. 2016 Feb;126(2):E51-6. doi: 10.1002/lary.25594. Epub 2015 Sep 15. PMID: 26371953.

20. Kilic M, Ufuk Altintas D, Yilmaz M, Güneşer Kendirli S, Bingöl Karakoc G, Taskin E, Ceter T, Pinar NM. The effects of meteorological factors and Alternaria spore concentrations on children sensitised to Alternaria. Allergol Immunopathol (Madr). 2010 May-Jun;38(3):122-8. doi: 10.1016/j.aller.2009.09.006. Epub 2010 Jan 19. PMID: 20089344.

21. Masaki K, Fukunaga K, Matsusaka M, Kabata H, Tanosak T, Mochimaru T, Kamatani T, Ohtsuka K, Baba R, Ueda S, Suzuki Y, Sakamaki F, Oyamada Y, Inoue T, Oguma T, Sayama K, Koh H, Nakamura M, Umeda A, Kamei K, Izuhara $\mathrm{K}$, Asano K, Betsuyaku T. Characteristics of severe asthma with fungal sensitization. Ann Allergy Asthma Immunol. $2017 \quad$ Sep;119(3):253-257. doi: 10.1016/j.anai.2017.07.008. Epub 2017 Aug 8. PMID: 28801088.

22. Osborne M, Reponen T, Adhikari A, Cho SH, Grinshpun SA, Levin L, Bernstein DI, LeMasters G. Specific fungal exposures, allergic sensitization, and rhinitis in infants Pediatr Allergy Immunol. 2006 Sep;17(6):450-7. doi: 10.1111/j.1399-3038.2006.00414.x. PMID: 16925691; PMCID: PMC2233910.

23. Hiranrattana A, Stern DA, Guerra S, Halonen M, Wright AL, Daines M, Martinez FD, Morgan WJ. Alternaria sensitisation at age 6 years is associated with subsequent airway hyper-responsiveness in non-asthmatics. Thorax. 2018 Dec;73(12):1170-1173. doi: 10.1136/thoraxjnl-2017210325. Epub 2018 Mar 21. PMID: 29563159; PMCID: PMC6410363.

Матеріал надійшов до редакції 29.10.2020 